
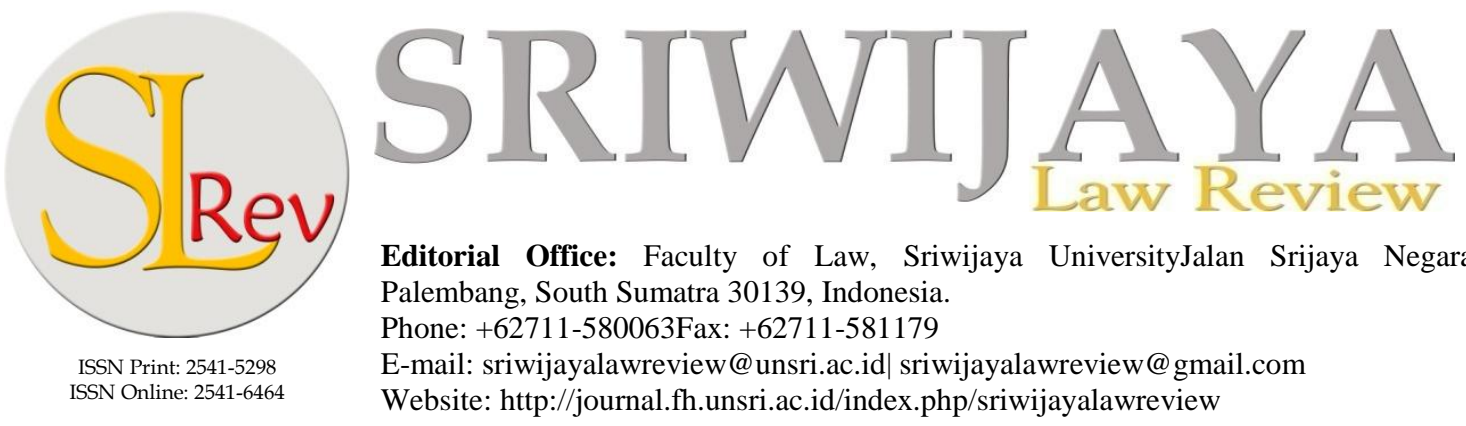

Editorial Office: Faculty of Law, Sriwijaya UniversityJalan Srijaya Negara, Palembang, South Sumatra 30139, Indonesia. Phone: +62711-580063Fax: +62711-581179

E-mail: sriwijayalawreview@unsri.ac.id|sriwijayalawreview@gmail.com Website: http://journal.fh.unsri.ac.id/index.php/sriwijayalawreview

\title{
Reconstruction the Paradigm of Law and Justice on the Regulation of Right to Living Space of the Orang Rimba Tribe in Bukit Duabelas, Jambi Province
}

\author{
Muhamad Erwin*
}

\begin{abstract}
The dominance of the positivism law paradigm in the management of forest areas at Bukit Duabelas in Jambi Province has created a crisis for the rights of a living space of Orang Rimba's tribe. Therefore, this requires further thoughts of the pattern of values and norms to be expansive with an emphasis on a quantity leading to a pattern of systemic values and norms emphasizing the quality of humanist and ecological aspects which complement and maintain each other. This article explores the paradigm of state law and customary law on the regulation of the rights to a living space of Orang Rimba's tribe, nomadic groups of people who live in wildwood, as well as ways of reconstructing it to fit the spirit of Pancasila.
\end{abstract}

Keywords: Paradigm; Positive law; Customary law; Right of living space; Pancasila.

\section{ARTICLE HISTORY:}

DOI: 10.28946/sIrev.Vol2.Iss1.110.pp56-68

Received: Apr 11, 2017;

Reviewed: May 10, 2017;

Accepted: July 10, 2017;

Published: Jan 31, 2018;

Citation: V.2.1 SLRev. 2018.

* Lecturer at State Polytecnic of Sriwijaya, Palembang, Indonesia.

E-mail:erwin_muhamad@ymail.com

\section{INTRODUCTION}

One of the objectives of the establishment of an Indonesian constitutional state is to "...protect the entire Indonesian nation and the whole of Indonesia's blood..."1. The aim of this Indonesian legal state is only to be approached in the need for a thorough understanding of the existing legal cultural diversity.

The multiplicity of Indonesian nation's legal culture is derived from the existence of various customary law community units, including remote indigenous communities (Komunitas Adat Tertinggal/KAT) as indigenous minority tribes that traditionally live in and around forest areas. ${ }^{2}$

\footnotetext{
${ }^{1}$ Fourth paragraph of The Preamble to the 1945 Constitution.

${ }^{2}$ Article 1 of paragraph 1 of the Presidential Decree Number 111 of 1999 concerning the Remote Indigenous Community Social Welfare Development.
} 
In relation to the definition of the living space of the remote native community, the existence of the Orang Rimba tribe in the Bukit Duabelas forest area is now legally governed by the legal considerations of letter $b$ of the Decree of the Minister of Forestry of the Republic of Indonesia No. 258 / Kpts-II / 2000, as follows:

"...in the northern part of the Nature and Nature Conservation Area (Biosphere Reserve) of Bukit Duabelas, is a place of the Orang Rimba (Orang Anak Dalam (Orang Rimba)) and is a lowland forest area remaining in Jambi Province, flora, fauna and ecosystems that need to be protected, and found various types of medicinal plants that are a source of livelihoods of the jungle."

As regulated by Regulation No. 5 of 1990 on the Conservation of Natural Resources and Ecosystems that if it has a status as a national park $^{3}$, then the management is done by the state with the zoning system, especially in the core zone that no activity at all should be carried out in it. ${ }^{4}$ Such an arrangement has clearly affected the narrowing or limited living space for the Orang Rimba tribe even though it is acknowledged in Bukit Duabelas National Park.

\footnotetext{
${ }^{3}$ Article 32 of Law no. 5 of 1990 on Conservation of Natural Resources and Ecosystems: National park areas are managed by a zoning system consisting of core zones, utilization zones, and other zones as required.

${ }^{4}$ Article 33 paragraph (1) of Law no. 5 of 1990 on the Conservation of Natural Resources and its Ecosystems: Everyone is prohibited from engaging in activities that may result in changes to the integrity of the park's core zone. Paragraph (2) Changes to the integrity of the core zone of the national park referred to in paragraph (1) include reducing, eliminating the function and area of the core zone of the national park, as well as adding other nonnative species and plants.
}

However, the statements and acknowledgments regulated in the Decree of the Minister of Forestry are essentially paradoxical, given the status of the national park for ecosystem protection and biodiversity (biosphere reserves) within it.

In addition, there are also paradoxes in the existence of legal uncertainty regarding the status of indigenous and tribal peoples based on the Indonesian legislation. On the one hand, Article 1 of paragraph (1) of the Presidential Decree No. 111 of 1999, the Orang Rimba tribe can be classified as a customary law community with a legal status of being a remote indigenous community. On the other hand, the Orang Rimba tribe cannot fulfill the provisions as stipulated in the provisions which can only be met if "there is clear customary law" defined as "settled" as can be seen in the Elucidation of Article 67 of paragraph (1) of Regulation No. 41 of 1999 on Forestry. The requirement of fulfilling the status of such a customary law society is to have made the Orang Rimba tribe community in Bukit Duabelas unable to do it because they have a seminomadic culture. ${ }^{5}$

Furthermore, based on the provisions of Article 67 paragraph (2) of

\footnotetext{
${ }^{5}$ The Orang Rimba tribe has a Belangun culture, that is, the habit of moving from one place to another within a relatively long distance due to death. Belangun is carried out to remove all the memories of the dead during his/her life. By waking up to other places it is hoped that a sad heart can be entertained with a new atmosphere. The occurrence of death in the Orang Rimba tribal settlement is also perceived as a land that is not good anymore to use because it will give bad luck as long as they survive to occupy it.
} 
Regulation No. 41 of 1999 on Forestry, the confirmation of the existence/ abolition of a customary law community is stipulated in a Regional Regulation. This requirement of legal status cannot be fulfilled by Orang Rimba tribe since up to now there has no single local government in Jambi Province having issued a law on the recognition of Orang Rimba tribe as a customary law community.

The existence of rigid requirements through the formulation of hypothetical legal norms has demonstrated a lot on the nuance of the legal positivism paradigm of legislation in Indonesia, especially in the forest management and its allocation. The paradigm of such legal positivism is more likely to place the rights of state control over the rights to control the people in relation to forest ownership and management.

The focus of this article is on the following issues: (1) How is the customary law paradigm of the Orang Rimba tribe the rights to their living space in Bukit Duabelas forest, Jambi Province ?; (2) How is the paradigm of state law positivism the rights of Orang Rimba tribe living space in Bukit Duabelas forest area, Jambi Province ?; and (3) How to reconstruct the legal paradigm of the Orang Rimba tribe living in Bukit Duabelas, Jambi Province?

\section{METHOD}

According to Thomas S. Kuhn, the term "paradigm" is used in two different meanings. On the one hand, it means the entire constellation of beliefs, values, techniques, and so forth shared by members of a particular society. On the other hand, the paradigm represents a kind of element in the constellation, the solving of a concrete puzzle that, if used as a model or example, can replace explicit rules as the basis for solving the stillremnant science puzzles. ${ }^{6}$ From that term, it is obvious that what is meant by the legal paradigm is none other than legal philosophy. In the Indonesian context, the legal philosophy is Pancasila as a pluralistic system of customary law philosophy in Indonesia.

Based on its history, Pancasila's legal philosophy is derived from the values reflected in customary law in Indonesia in general, to be subsequently established as a fundamental basis for the enactment of state law. Taken from the nomus, to then become the norm. This simple reasoning is sufficient to state that state law should not conflict with the customary law. However, in reality, it is not so. Satjipto Rahardjo expresses his concerns as follows:

"We often express our pride as a virtuous nation; moral, family, togetherness, and the like. However, it does not penetrate to our legal culture. Culture is even more likely to individualism. All morality is not yet our social capital (SC). ${ }^{17}$

As the customary law and character of the Indonesian people are open to change, the national legal system is also open to change, as long as the change is

\footnotetext{
${ }^{6}$ Thomas S. Kuhn, The Structure of Scientific Revolutions: The Role of Paradigms in the Science Revolution, PT Remaja Rosdakarya, Bandung, 2000, p170.

${ }^{7}$ Satjipto Rahardjo, Membedah Hukum Progresif, Editor: Joni Emirzon, I Gede A.B. Wiranata, Firman Muntaqo, Book Publisher Kompas, Jakarta, 2006, p6.
} 
both moral and religious, just for all, and happy for everyone when changed.

The reconstruction of this legal paradigm is intended to allow the law of the state to provide prosperity and justice for all the people of Indonesia, including providing protection for the rights to a living space for the Orang Rimba tribe in Bukit Duabelas. According to John Rawls, the "unfair" condition that needs to be reformed is when the dominance of freedom or freedom is given to one group interferes with the freedom of the other. $^{8}$

In addition, if viewed from the form of legal research that answers the problems in this study by combining normative legal research and empirical research in the law field, then this type of research is categorized as a sociolegal research. It is viewed as such since it departs from the notion that law as nomus and norm with law as a social living space is an ever-connected entity, as revealed by Cicero in the adage of sweet potato societies, ibi ius (where there is a society, there is a law), then according to the authors, a legal study requires a dialectic between legal doctrine and social space in its living space. Therefore, the legal research conducted by the authors of this study is a legal socio-legal research that combines legal studies and social studies of law.

\section{ANALYSIS AND DISCUSSION}

\footnotetext{
${ }^{8}$ John Rawls, Teori Keadilan: Dasar-dasar Filsafat Politik Untuk Mewujudkan Kesejahteraan Sosial Dalam Negara, Translated by Uzair Fauzan and Heru Prasetyo, Pustaka Pelajar, Yogyakarta, 2011, p256.
}

Paradigm of Customary Law of Orang Rimba Tribe on the Rights to Living Space In Bukit Duabelas Forest Area, Jambi Province

Thomas Kuhn states that the human communities will only be able to maintain their existence on the basis of their ability to develop the same pattern or model of thought to define their knowledge, to then be utilized as the most normal life support. ${ }^{9}$ Thus, not all community groups have a paradigm or similar understanding of various aspects of life. Like the construction of Aristotelian paradigm thinking in the understanding that the universe as a single order is preestablished, final, all-diesel and teleological (teleos = purpose) is "not to be disturbed". ${ }^{10}$

Such interpretation in modern interpretation is called metaphysical interpretation (commentary outside physics). According to Suriasumantri, the metaphysical interpretation is found in supernatural (supernatural) forms and these are higher or more powerful than the real nature. ${ }^{11}$ This magical-religious metaphysical interpretation still occupies the first position in the customary law of the Orang Rimba tribe in Bukit Duabelas which is still guarded by their descendants.

The nuance is so reflected in the understanding of the people of the Orang Rimba in Bukit Duabelas who know the

\footnotetext{
9 Soetandyo Wignjosoebroto, Pergeseran Paradigma Dalam Kajian-Kajian Sosial dan Hukum, Press Release, Malang, 2013, pp9-10.

${ }^{10}$ Note 9 p 12 .

${ }^{11}$ Jujun S. Suriasumantri, Filsafat Ilmu, Sebuah Pengantar Populer, Sinar Harapan Library, Jakarta, 2001, p64.
} 
existence of four realms, namely ${ }^{12} \mathrm{Ha}-$ lom Bahelo, the life of God, Halom Dewo, the realm of god life believed to be an intermediary to connect with God; Halom Nio, the natural place of human life, and Halom Kafir, the realm of land believed to be the source of all diseases.

Through their traditional knowledge, Orang Rimba tribe people are able to raise the order of values (nomus) into norms (norms) that are wise in relation to the natural forests of Bukit Duabelas. Departing from the foundation of the Orang Rimba tribe in the forest of Bukit Duabelas which is so related to the existence of Bukit Duabelas forest cosmos, all the life cycle of Orang Rimba tribe from birth to death is related to forest ecology of Bukit Duabelas.

The subsequent runway is transferred to spatial knowledge, i.e., as knowledge of space in observation units, where the forest area that becomes the living space for the Orang Rimba tribe, as well as the demand for customary tenure rights to the forest, is expressed in Seloka indigenous Orang Rimba tribe, "Pangkal Waris Tanah Garo, Ujung Waris Tanah Serengam dan Air Hitam Tanah Berjenang". ${ }^{13}$ (The base of the Garo Garut Land, the Edge of Serengam Land and the Soil Black Water).

Then the spatial knowledge is flowing to kinematic knowledge, that is, as the knowledge of the implementation. Kinematically, in the utilization and management of resources in Bukit Dua-

\footnotetext{
${ }^{12}$ Interviewed with Besemen, Mangku Adat of Orang Rimba Kedundung Muda Area (Bukit Duabelas), Sunday, May 22, 2016.

${ }^{13}$ Interviewed with Besemen, Mangku Adat of Orang Rimba Kedundung Muda Area (Bukit Duabelas), Sunday, May 22, 2016.
}

belas forest, Orang Rimba regulate their position in the form of a region consisting of rimbo, beumo (farming), then becoming sesap, the bearer, and then benuaron. In addition, there is also a religious magical region in the form of tanoh peranokan and tanoh pasaron. Rimbo is seen by Orang Rimba as a forest area of Bukit Duabelas belonging together as a place of wanderings in meeting the needs of life by hunting or gathering.

From such kinematic knowledge, the next is physical knowledge, i.e. as knowledge of substance. Physically, Orang Rimba tribal customs occur from the life situation of the Orang Rimba tribe when faced with the natural conditions of Bukit Duabelas, which means that Orang Rimba tribe never remains silent in dealing with selfdetermination, an interaction between themselves and outsiders, and in their relationship with the nature of Bukit Duabelas.

After understanding the physical knowledge, the next is the knowledge of biotic (life). Knowledge of life, the title of "Orang Rimba" itself, is basically an interpretation of the identity of their life which views the customs and forests of Bukit Duabelas as the main key of their lives since their ancestors as their customs "adat lamo pesako usang" meaning old custom will not change, nor so in the wisdom of keeping the Bukit Duabelas as the living space.

Furthermore, after resting on biotic knowledge, subsequent knowledge is transformed into psychic knowledge, which means knowledge of consciousness. Psychologically, the Orang Rimba 
tribe people in the forests of Bukit Duabelas reflect themselves by following all the wisdom. This is related to the rights to their living space in Bukit Duabelas forest by following the natural instinct of their spontaneous feelings, even if there is an occult arrangement. From what they have seen so far, with them following the rules of customary law, things seem to go without hindrances.

After that, the awareness (psychic knowledge) of the Orang Rimba tribe is transformed into socio-cultural knowledge, namely knowledge of civilization. In the social-cultural knowledge, the Orang Rimba tribe defines the existence of Bukit Duabelas forest as a form of cosmic balance and socio-cultural balance. The cosmic and socio-cultural balance shown in the Orang Rimba tribe's interaction in Bukit Duabelas forest is seen by Orang Rimba tribe as something of value so that it can inspire respect and give birth to the behavior of the protection and care of the living space.

From after going through such a solid nominal process, it is then raised to the norm (norm) in the customary law which then sees Bukit Duabelas as an heirloom with the regulation of the norms cycle through their customs as follows. Heirloom (pesako) in the understanding of the Orang Rimba tribe in Bukit Duabelas is anything sacred or denied to be broken because it can lead to a disaster. So then the customary legal norms of the Orang Rimba tribe that are peculiar to the place of life and the way of life of the Orang Rimba tribe are designated as the basic benchmarks for the customary heirs in order to distinguish them from the lives of people outside in general.

From the chronological explanation of the rise of the numus to norm in the Orang Rimba tribe society in relation to Bukit Duabelas as their living space as it is, the dynamics are in accordance with Rahardjo's view that the law is the product of human construction, whether it is social, political or cultural construction. ${ }^{17}$ In terms of aspects of its usefulness, the customary law paradigm of Orang Rimba tribe with various traditional wisdom can keep their forests remain sustainable.

${ }^{15}$ Note $11, \mathrm{p} 33$. 


\section{Paradigm of Law against Right of the Living People's Spaces in Bukit Duabelas}

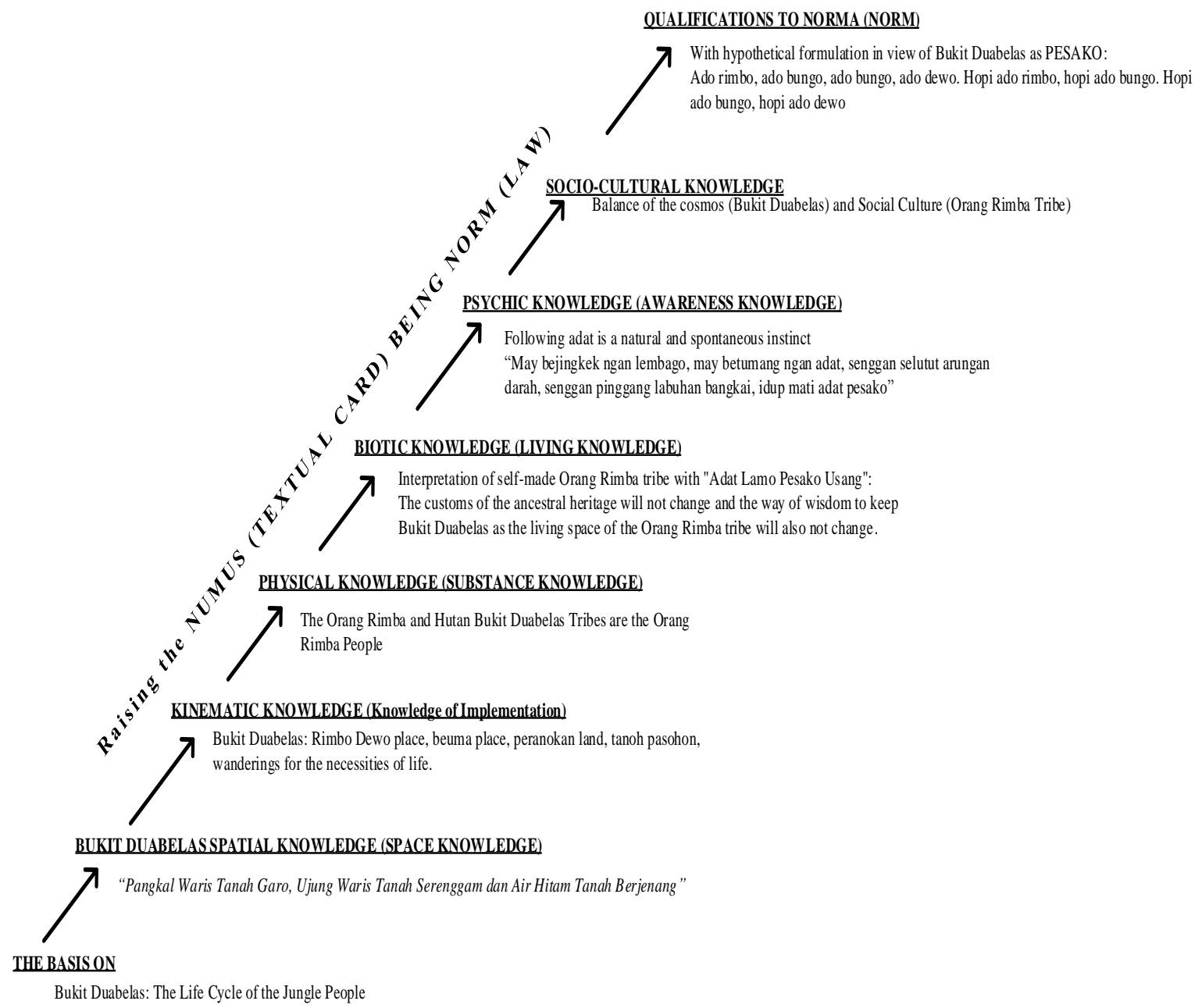

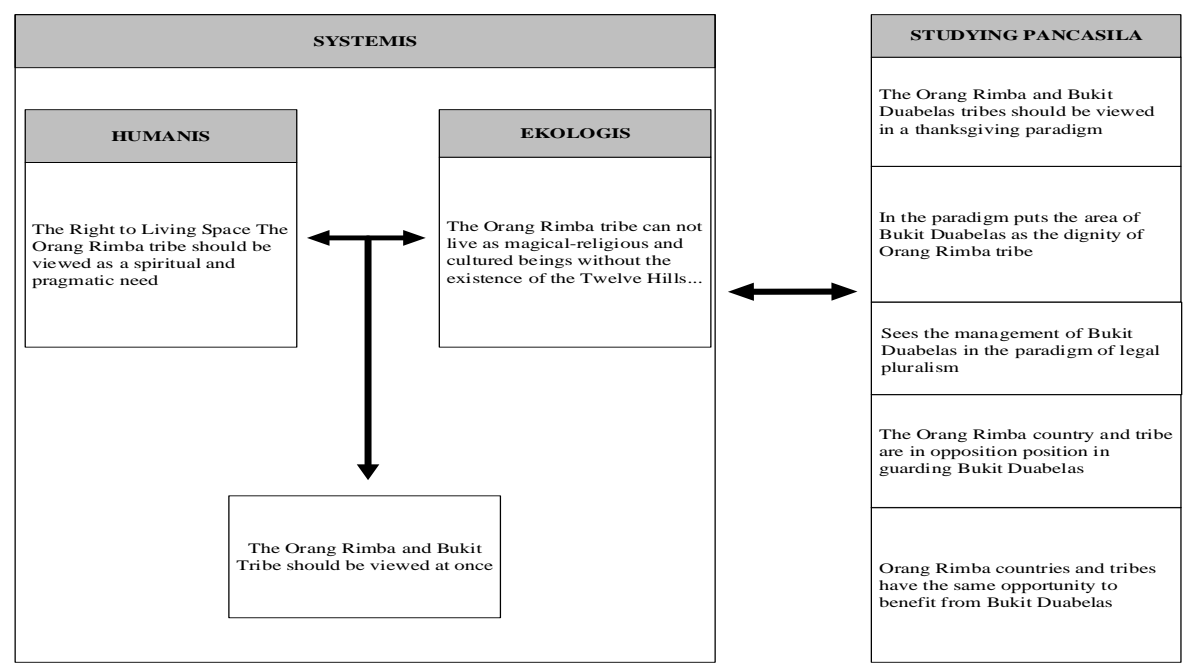




\section{Reconstruction of the Legal Paradigm against the Regulation of the Right to Liv- ing Room of Orang Rimba Tribe in Bukit Duabelas in The Framework of Systemic Paradigm Pancasila}

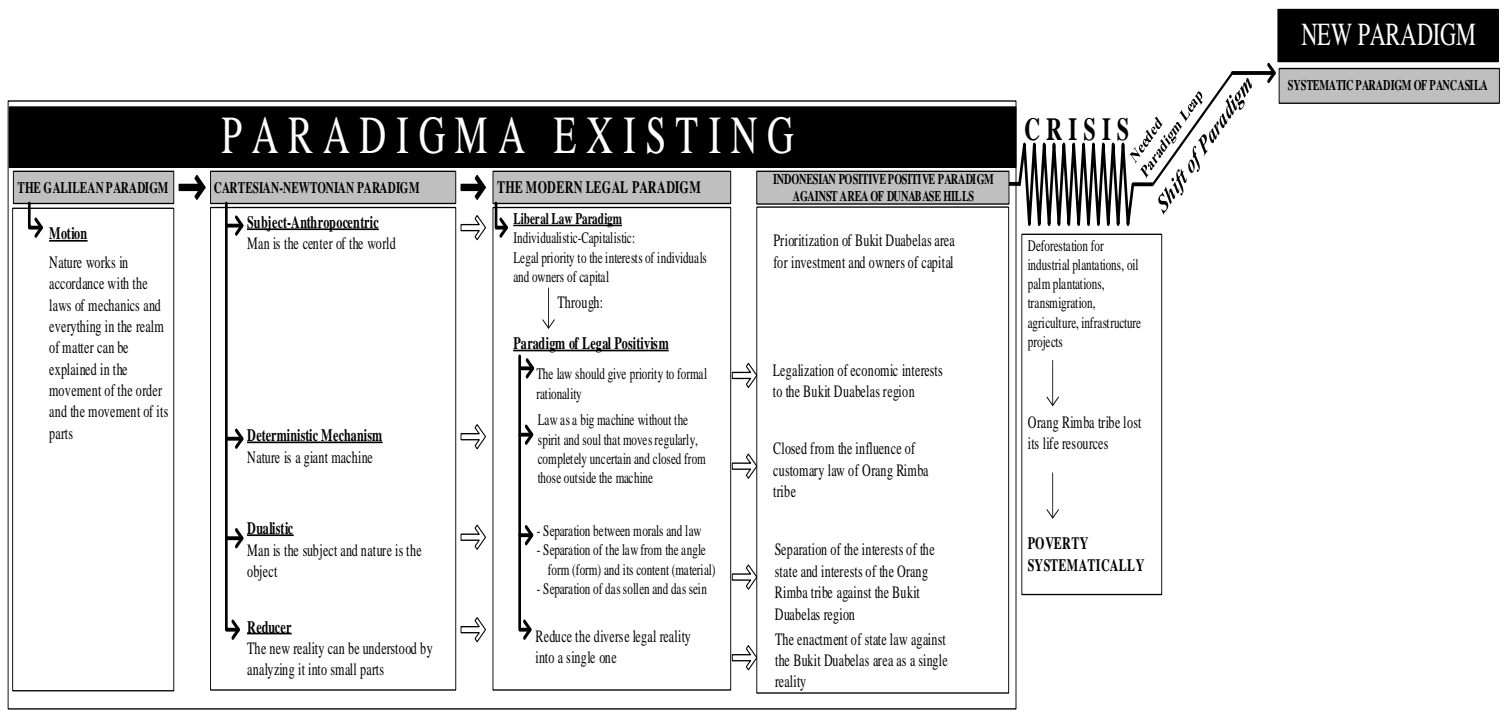

The traditional cultural phenomenon of the tribe of Orang Rimba in Bukit Duabelas as described in the first discussion is currently continuously depressed in unison with the state's perspective departing from the Galilean paradigm, then developed through the Cartesian and Newtonian paradigms, which are further introduced through the legal positivism paradigm.

In its development, then the characters of the Cartesian-Newtonian paradigm become the existing paradigm and then they are introduced into the positivistic legal paradigm. The influence of the character of legal positivism shows that the law is a great machine without a spirit and a soul, moves erratically at all and is closed to changes that exist outside the machine. ${ }^{15}$

With the mechanistic character of the closed legal positivism of all that is outside the machine, it certainly does not give a place against the customary law paradigm of the Orang Rimba tribe in Bukit Duabelas that is religiously magical. In the end it leads to the rejection of moral teachings in customary law because it comes from elements of a doubtful nature, as many have been the way of the local government's view, from the Bukit Duabelas National Park Office, the palm oil companies, the community transmigration villages, and Malay village communities around Bukit Duabelas.

Furthermore, with the characteristic of superiority, as Kelsen's teachings reduce the divergent reality of law into single or Austin who assumes that law is a sovereign command to reduce forces other than the state, especially the forces that live in very diverse societies.

Superiority in legal positivism is also shown through the concept of the rights of state control to subdue the exis- 
tence of indigenous and tribal peoples. With the conception of the state's rights to control under a number of agrarianrelated legislation, the state has unfairly taken over the rights of the Orang Rimba tribal space in Bukit Duabelas through the rights of forest management, industrial plantation forest, palm plantation permits, transmigration or through conservation.

Legislation relating to the regulation of the management of living space and natural resources as the rights of indigenous peoples is always accompanied by the phrase "as long as it is not contrary to the national interest" or "as long as it exists and is recognized and so on". In this way, the government carries out legal politics with neglect of legal pluralism that actually lives and prevails in indigenous peoples. So even in the political level of the law of the state which always wants to issue the Orang Rimba tribe from the forest of Bukit Duabelas through PKMT program (Resettlement of Distanced People) because the status area of Bukit Duabelas is a national park.

With so diminished access to natural resources in Bukit Duabelas forest today, it forces the Orang Rimba tribe to adapt to the new natural environment. But the limited ability of both skill and economy makes it difficult for them to find new ways of living. The current condition of Orang Rimba tribe is very apprehensive. Today there are many Orang Rimba tribal groups living in a very specific ecological niche. This group relies on living from exotic sources that are not commonly used, such as by eating a kind of tuber (Dioscorea hispida).
Though life is an option, essentially no human being may regulate and injure the rights of living of another person whose nature is a human right. As set out in the opening section of the United Nations Declaration on the Right of Indigenous People, it is emphasized that every human being should respect the rights of indigenous peoples and promote such rights in relation to the political, economic and socio-cultural aspects, region, territorial boundaries and deep resources contained within the tribal habitat. ${ }^{16}$

Reflecting on the dynamics of the crisis suffered by the Orang Rimba tribe community in Bukit Duabelas, it is necessary to have a shift of paradigm that is deemed capable of reconstructing the existing paradigm of state law through a paradigm that can unite humanist and ecological aspects simultaneously.

Today the people of the Orang Rimba tribe in Bukit Duabelas have seen the doomsday threat of the destruction of Orang Rimba and all life in Bukit Duabelas is very real). With this understanding it can be said that the living space crisis experienced by the Orang Rimba tribe is also related to the crisis of legal understanding of the Orang Rimba tribe's nature as indigenous and tribal people, to the nature of Bukit Duabelas' natural and ecosystems, and to the relationship between Orang Rimba tribes in the whole ecological nature of Bukit Duabelas forest.

\footnotetext{
16 "Recognizing the urgent need to respect and promote the inherent rights of indigenous people which derive from their political, economic and social structure and from their cultures, spiritual traditions, histories and philosophies, especially their rights to their lands, territories and resources" (Preamble, UN Declaration on the Rights of Indigenous People).
} 
This means that the existing paradigm of existing law and justice is no longer able to explain the reality of the rights to the living space of the Orang Rimba tribe in Bukit Duabelas. From such a cycle of dynamics, the crises and disasters of the Orang Rimba tribe's living in Bukit Duabelas can only be overcome by finding a new way of viewing the rights to their living space in Bukit Duabelas. The paradigm shift here is intended to rebuild the changes concerning the thinking, understanding, worldviews, changes in values and behaviors ascribed to the laws of the state to the reality experienced by the Orang Rimba tribe community in Bukit Duabelas.

In relation to the need for a change of paradigm of law and justice that can conform to the legal needs of the Orang Rimba tribe's living rights for the happiness of the Orang Rimba tribe and people in Bukit Duabelas, it will be reconstructed through a new paradigm of systemic paradigm with the spirit of Pancasila.

Starting from a systemic point of view, as a way of thinking about reality as a whole as an interspersion and intrinsic relevance among all natural phenomena and life in it, both physical, biological, psychological, social and cultural. ${ }^{17}$

In this systemic way, the Orang Rimba and Bukit Duabelas tribes should be regarded at once, since it must be understood that Orang Rimba is an entity from Bukit Duabelas forest. A worldview that is born out of a pattern of relationships between the Orang Rimba tribe

\footnotetext{
${ }^{17}$ Fritjof Capra, The Turning Point: Science, Society, and the Rising Culture, Bantam Books, California, 1983, p17.
}

and Bukit Duabelas forest that fills each other in mutually supportive and supportive relationships. A perspective derived from a basic understanding that man is not only a social being but also as an ecological creature, the Jungle cannot develop into a complete self without the ecosystem and without contact with the entire Bukit Duabelas forest.

The Forests of Bukit Duabelas is understood by Orang Rimba as a basic entity with their lives, therefore maintaining the forests of Bukit Duabelas means preserving the life of Orang Rimba. From this understanding, it appears that humanistic and ecological aspects develop simultaneously.

The harmony in humanism in the legal and justice paradigm of the rights to the living space of the Orang Rimba tribe in Bukit Duabelas is viewed as a whole as a way of preventing the natural ecology of Bukit Duabelas forest from falling apart. The disappearance or shrinking of harmony in the humanism appreciation of the Orang Rimba will be seen as a sign of the decomposition of natural elements of Bukit Duabelas forest.

Against the elements that support the natural forests of Bukit Duabelas, efforts to maintain harmony are explained in various rituals, where the ties between Orang Rimba, forest, crops and supernatural powers are confirmed in equilibrium. The indigenous poem and spell of Orang Rimba tribe people are directly oriented to the whole elements that support the natural forests of Bukit Duabelas. Likewise, taboos and adat sanctions for violations of these matters are all oriented to maintaining harmony 
between the humanitarian treatment of the Orang Rimba tribe and the sustainability of Bukit Duabelas forest.

Without clean water of small streams of Bukit Duabelas, the Orang Rimba will be sick. Without the Bukit Duabelas forest, there will be no food. Thus, there is a series of life webs that are tightly knit in the ecosystem that enables life, both the Orang Rimba's life and the life of the Bukit Duabelas forest in general. Without the forest of Bukit Duabelas, there is no life in the economic level of Orang Rimba. Even from a cultural point of view, Orang Rimba tribe cannot live as religiously and culturally magical beings without the existence of Bukit Duabelas forest. Culturally, Orang Rimba depends entirely on Bukit Duabelas forest. Culture in question is found in ritual ceremonies (bedewo), marriage (bebalai), Thanksgiving, rejection, family relationships, including funeral ceremonies (pemakoman). All are determined by the ecosystem in Bukit Duabelas forest.

The Culture of the Orang Rimba tribe is the result of all system processes related to each other in Bukit Duabelas forest with all its life, including the animals and plants living there. Therefore, both the Orang Rimba tribe and the animals and plants in the forest of Bukit Duabelas have the same rights to grow together in the process of mutual influence between them and the influence of each other with the surrounding ecosystem.

It means existentially that the Orang Rimba tribe in the paradigm of law and justice for the rights to their living space in Bukit Duabelas forest must be sys- temically understood to unite humanist and ecological conception. It is important that the systemic paradigm must also pioneer Pancasila, namely as a binding paradigm of togetherness between regions of diverse ethnic groups in Indonesia. The meaning of Pancasila for the systemic paradigm can always be connected to each of its principles.

By striving on the values of divine morality as stated in the first principle of Pancasila, it soon unfolds that the state law's paradigm of justice to the living space of the Orang Rimba tribe in Bukit Duabelas must be harmonized with the Creator, in a harmony pattern of the grace of the Almighty. With the paradigm of gratitude, there will be an understanding of ethics that protects the rights to living space of Orang Rimba tribe to mean taking care of the sustainability of Bukit Duabelas forest. Taking care of both means keeping life. Thus, the legal and justice paradigm of the right to the living space of the Orang Rimba tribe in Bukit Duabelas must have an ethical, natural and divine basis.

In the relationship between the precepts of humanity and the right to the living space of the Orang Rimba tribe in Bukit Duabelas, there must be a legal construction which can create the awareness of each party to treat the Orang Rimba tribe as an individual in full and enable them to live up to their human dignity.

Meanwhile, the relationship between the existence of the precepts of the Unity of Indonesia and the issue of the legal and justice paradigm of the rights of the living space of the Orang Rimba tribe in Bukit Duabelas which needs to 
be aspired is not the law of the country that kills the customary law of Orang Rimba tribe, but it is a legal and justice paradigm emerging from intensive interaction with customary law of Orang Rimba tribe in Bukit Duabelas. Through this epistemological knowledge of pluralism, the legal system governing the rights of the Orang Rimba people's living space is no longer as a rigid entity, in which the customary law system of the Orang Rimba tribe and the legal system of the state can complement each other. The compromise between the two traditions based on each legal element is possible to provide a solution to the difference.

With the paradigm of the people's holiness, formulating how the paradigm leap that must be built in laying the paradigm of law and justice to the rights of the Orang Rimba tribe living in Bukit Duabelas must be placed on the existence of the Orang Rimba tribe people having rights, obligations, and responsibilities together with the state over the existence of Bukit Duabelas forest.

While through the social justice for all Indonesians, it is necessary that the Orang Rimba tribe should be seen as having equal opportunity with the state in receiving benefits from Bukit Duabelas forest, in the interest of the rights to their living space to maintain their alliance to continue their existence and can sustain their life personally.

\section{CONCLUSION}

The Orang Rimba tribe's way of thinking about the rights to their living space in Bukit Duabelas forest is by raising the order of values (nomus) into norms that are wise with the foundation's construction modalities, space knowledge, kinematic knowledge, physical knowledge, living knowledge, and socio-cultural knowledge.

The perspective of the positive law of the state against the existence of Bukit Duabelas which is the living space of Orang Rimba tribe is so influenced by the Cartesian-Newtonian paradigm and the capitalistic industrialization demands by providing rationality and predictability in economic life. In support of the way of thinking there happens the centralism of state law by ignoring the existence of the customary law of Orang Rimba tribe.

The reconstruction of the paradigm of law and justice to the regulation of the rights of the Orang Rimba tribal space in Bukit Duabelas is by making a leap of thought from the existing legal paradigm to positivistic mechanistic that it is difficult to achieve justice to the paradigm that connects the systemic legal paradigm to the Pancasila law paradigm. Thus there will be a dialectic between the systemic legal paradigm as a way of thinking about reality as a whole and as an interspersion and intrinsic relevance between all natural phenomena and life in it physically, biologically, psychologically, socially and culturally (humanist and ecological) and the paradigm of Pancasila.

\section{REFERENCE}

Capra, Fritjof, 1983, The Turning Point: Science, Society, and the Rising Culture, California: Bantam Books.

Kuhn, Thomas S., 2000, The Structure of Scientific Revolutions: The Role of 
Paradigms in Revolution Science, Bandung: PT Remaja Rosdakarya.

Rahardjo, Satjipto, 2003, Sisi-sisi Lain Dari Hukum Di Indonesia, Jakarta: Book Publishers Kompas.

, 2006, Membedah

Hukum Progresif, Editor: Joni Emirzon,

I Gede A.B. Wiranata, Firman Muntaqo, Jakarta: Book Publishers Kompas.

Rawls, John, 2011, Teori Keadilan: Dasar-dasar Filsafat Politik Untuk Mewujudkan Kesejahteraan Sosial Dalam Negara, Translated by Uzair Fauzan and Heru Prasetyo, Yogyakarta: Student Literature.

Suriasumantri, Jujun S., 2001, Filsafat Ilmu, Sebuah Pengantar Populer, A Popular Introduction, Jakarta: Pustaka Sinar Harapan.

Susanto, Anthon F, 2010, Dekonstruksi Hukum: Eksplorasi Teks dan Model Pembacaan, Yogyakarta: Genta Publishing.

$$
\text { 2010, Ilmu }
$$

Hukum Non Sistematik: Fondasi Filsafat Pengembangan Ilmu Hukum Indonesia, Yogyakarta: Genta Publishing.

Wignjosoebroto, Soetandyo, 2013, Pergeseran Paradigma Dalam KajianKajian Sosial dan Hukum, Malang: Equivalent Press. 